\title{
Article
}

\section{Can China's Belt and Road Initiative be Reconciled with the EU's Multilateral Approaches to International Law?}

\author{
Ernst-Ulrich Petersmann ${ }^{*} \&$ Giuseppe Martinico ${ }^{* *}$
}

This article focuses on China's Belt and Road Initiative (BRI) as a potential cause of trade, investment, financial, maritime, energy trade and intellectual property disputes. In so doing this contribution discusses the increasing "systemic rivalry" among authoritarian, neoliberal and ordo-liberal conceptions of international economic law and the resulting legal problems in the settlement of BRI disputes inside the EU countries, whose courts may not recognize arbitration awards by Chinese arbitration institutions and may hold Chinese investors accountable for disregard for human and labor rights in their BRI investment inside the EU countries.

Keywords: China, Belt and Road Initiative, Bilateralism, Soft-Law, European Union, Multilateralism, International Law

* Emeritus Professor of International and European law at the European University Institute (EUI), Florence, Italy; former legal adviser in the German Ministry of Economics, GATT and the WTO; former secretary, member of chairman of GATT and WTO dispute settlement panels; and former representative of Germany in the EU, UN and other international institutions. Dr. iur. (Heidelberg). The author may be contacted at: Ulrich.petersmann@eui.eu/Address: European University Institute, Via Bolognese 156-50139 Firenze, Italy.

** Associate Professor of Comparative Public Law, Scuola Superiore Sant'Anna, Pisa, Italy. Dr.iur. (Scuola Superiore Sant'Anna Pisa) ORCID: http://orcid.org/0000-0002-2003-3745. The author may be contacted at: giuseppe.martinico@santannapisa.it/Address: Scuola Superiore Sant'Anna, Piazza Martiri della libertà 33, 56127, Pisa. This article originates from an international conference organized in Pisa on May 24, 2019 within the frame of the Sant'Anna Legal Studies (STALS) initiative, a project made possible thanks to the financial support offered by Scuola Superiore Sant'Anna, issued within the framework of the School's internationalization policy. The conference was organized after the signature of the Memorandum of Understanding between China and Italy and was kindly funded by the Confucius Institute of Pisa.

All the websites cited in this article were last visited on August 5, 2020. 


\section{INTRODUCTION}

The Belt and Road Initiative (BRI) is a multi-functional strategy launched by the People's Republic of China (PRC), which is based on a variety of instruments and measures. The priorities of the BRI are multiple and ambitious, including policy coordination, infrastructure connectivity, unimpeded trade, financial integration, people-to-people bond and development through six geographical corridors. ${ }^{1}$ As is evident, the realisation of this initiative will take ages and is part of a grand strategy, which may be interpreted in different ways.

So far, the debate on the topic has mostly been dominated by scholars in international relations and geopolitics and economists. ${ }^{2}$ More recently, lawyers tried to enter this interdisciplinary debate. However, with the above-mentioned exceptions, the very few legal analyses that exist on this ambit are still superficial. ${ }^{3}$ Contributions on the topic are often only descriptive and include only few critical legal approaches. This article takes a more legal approach by asking what does the BRI contribute to international law, dispute settlement procedures and multilateral organizations?

This article will focus on China's BRI as a potential cause of trade, investment, financial, maritime, energy trade and intellectual property disputes. In so doing this contribution discusses the increasing "systemic rivalry" among authoritarian, neoliberal and ordo-liberal conceptions of international economic law and the resulting legal problems in the settlement of the BRI disputes inside the EU countries, whose courts may not recognize arbitration awards by Chinese arbitration institutions and may hold Chinese investors accountable for disregard for human and labor rights in their BRI investment inside the EU countries. Moreover, another factor which is perceived as problematic from the EU perspective is the bilateral approach employed within the BRI, which may threaten legal uniformity as promoted and preserved, for instance, by the Court of Justice of the EU (CJEU) in its legal system as shown by such decisions as Melloni. ${ }^{5}$ In this respect, some Memoranda of Understanding (MoU) concluded by China and some EU Member States have been seen as hostile. Another source of uncertainty is related to the use of soft law measures. We will discuss these phenomena while analyzing the case of the MoU concluded between China and Italy. 


\section{The Belt and Road Initiative as Soft Law}

Why do China and many other Asian countries conclude less multilateral trade and investment agreements than most European countries? Can the principles underlying China's large number of bilateral agreements with Silk Road countries substitute for a multilateral agreement, for instance, due to the most-favoured nation commitments in China's bilateral investment treaties (BITs) with many Silk Road partner countries? ${ }^{6}$

Bilateralism as understood in the BRI relies on soft law. Indeed, soft law has acquired a growing relevance as scholars have stressed: "BRI-related soft law documents arise through a myriad of forms and involve a large number of parties. In terms of form, these instruments are generally found to be cooperation agreements, including joint communiques, joint statements, agreements, a MOA, MOUs, a letter of intent, initiatives and consensuses." ${ }^{7}$

Flexibility is one of the pillars of the BRI, which already represents an explanation of this massive use of soft law instruments. However, flexibility means different things when applied to the BRI, having both a normative and institutional dimension ${ }^{8}$ as we will see. Another reason why soft law instruments are vital in this area is due to the "partnership-based relational approach" promoted by the Initiative:

\footnotetext{
Being "relational" means the cooperative framework for the BRI is not based on a treaty-based institutional design. Rather, it utilizes a variety of means, most of which are rather abstract and even ambiguous, with the view to building confidence and developing good relations through volunteer cooperation and non-binding promises. The "partnership" dimension in the BRI indicates that the bilateral cooperation between China and individual BRI countries is always oriented toward building partnership, for which the BRI does not impose a uniform model applying to all countries. Rather, China seemingly seeks a model of "One Country One Approach" (yiguo yice). That is, China's bilateral cooperation with each and every BRI country can adopt a different model, as long as it is mutually acceptable solution through friendly bilateral negotiations. ${ }^{9}$
}

This variety does not exclude fruitful comparison between different MoUs, but explains why it is possible to find some differences between those concluded between China and developing countries and those concluded instead between China and 
developed countries as suggested by scholars. ${ }^{10}$ Apart from these differences, the MoU seems to follow a common scheme which then refers to other acts (statements, policy documents), triggering a sort of cascade system, where the MoU is understood as part of a legally hybrid jungle in the sense described by Trubek, Cottrell and Nance. ${ }^{11}$ From a methodological point of view, this proliferation of measures should not be studied adopting a formalistic approach but relying on a pragmatic view. This is because "the BRI is a holistic exercise: China promotes the BRI through all possible means and coordinated efforts." "' As Snyder pointed out in his seminal studies, soft law should not be seen as legally irrelevant. As in other legal fields, it may acquire juridical importance. This point has been stressed by Wang in the field of the BRI as well:

\begin{abstract}
While these BRI-specific soft law documents are not binding, they nonetheless should not be ignored. China currently prefers to avoid engaging through treaties, with measurable compliance requirements, in favour of less formal, but more flexible, arrangements. BRI-specific documents usually call for voluntary forms of cooperation, or statements of future intent, instead of imposing hard law treaty obligations backed by enforcement mechanisms. For example, the MOA and MOUs under the BRI are nonbinding documents. However, they are nonetheless essential to BRI implementation. ${ }^{13}$
\end{abstract}

Soft law is a very ambiguous concept given the difficult location of this category in the classic hierarchy of sources. These have been defined by Snyder as "measures which are not legally binding but which nevertheless have practical and even legal effects. ${ }^{, 14}$ Scholars have identified the following features for this type of norms:

[T]hey have been articulated in non-binding form according to traditional modes of law-making; (ii) they contain vague and imprecise terms; (iii) they emanate from bodies lacking international law-making authority; (iv) they are directed at non-state actors whose practice cannot constitute customary international law; (v) they lack any corresponding theory of responsibility; (vi) they are based solely upon voluntary adherence, or rely upon non-juridical means of enforcement. ${ }^{15}$

In other words, we are speaking of legally relevant norms that are sometimes included in non-binding acts, which differ from hard law due to the different prescriptive intensity, and whose "main differentiating features lie in the capacity of the norm 
to prescribe legally binding commitments, the clarity and precision of its terms, and its enforceability."

In the BRI, the preference for soft law can be also explained in light of cultural reasons. ${ }^{17}$ Comparative law scholars suggest:

\begin{abstract}
At times, soft law can trump hard law in instances where a court or arbitral tribunal recognizes something as international customary law that pre-empts the application of attributable domestic hard law (choice of law or conflicts of law). Such a dichotomy is also at work in domestic legal systems. This is especially true in China, which has a long history of informal customary law. Indeed, in China's case hard law (CCL, CISG, General Rules, administrative regulations) is insufficient to truly understand the role of law in Chinese society [...] Chinese cultural norms weigh in favor of mediation, compromise, and relationship preservation than it does to litigation. Second, rational judicial reasoning in the application of hard rules and principles is lacking in the Chinese judiciary because of its lack of skill and familiarity with the Western legal concepts found in the CCL [...] In China's case, cultural norms (Confucianism, guanxi, socialistic communal-collective ideals) are, in a sense, the law behind the law. The meaning attached to the hard rules of contract is heavily influenced by this normative background, which one scholar has characterized as the "normative richness of life in China. ${ }^{18}$
\end{abstract}

When this cultural humus is coupled with what Heng called "institutional flexibility" (i.e., the absence of a common structural frame) the outcome results in giving soft law a role completely different from that played, for instance, in the context of EU law. This explains why soft law has become 'trendy' in China ${ }^{19}$ : An important "Soft Law Centre" has been set up at the Peking University, where also an eminent scholar in the field, Francis Snyder, currently works.

\title{
III. The MoU between China and Italy
}

Italy and China entered into a MoU signed by President Xi Jinping and Prime Minister Giuseppe Conte on March 23, 2019. The conclusion of this agreement has always been surrounded by concerns as to the potential clash of this deal with Italy's duties stemming from its NATO and EU memberships. This point was apparently balanced by the references to international law obligations included in the MoU. 
The language of the agreement is very vague. But this MoU has great political and symbolic importance because Italy is a G-7 and founding member of the EU. Indeed, the agreement has caused many concerns among other EU Member States. This agreement has been complemented by other agreements (nineteen, to our knowledge) concluded in specific sectors, such as culture, sport, energy, finance and infrastructure. Plus, the harbours of Trieste and Genova have concluded other agreements with the China Communications Construction Company. ${ }^{20}$ The MoU reflects the usual structure followed in these cases; it is a seven-page document divided into six paragraphs. Paragraph I is devoted to the "Objectives and Guiding Principles of Cooperation." It states that the bilateral cooperation will be developed consistently with "the purposes and principles of the UN Charter." Compliance with national and international law is also recalled later in the same provision, when it is stated that "[i]n accordance with their respective domestic laws and regulations, consistent with their respective international obligations." Paragraph II recalls the "Areas of Cooperation," namely "Policy dialogue," "Transport, logistics and infrastructure," "Unimpeded trade and investment," "Financial cooperation," "People-to-people connectivity" and "Green development cooperation." Apart from the "Green development cooperation," the other areas respond to the priorities already listed in the "Vision for Maritime Cooperation under the Belt and Road Initiative." 21 Paragraph III is devoted to the "Modes of Cooperation," where a non-hard list of ways to cooperate is identified. Also, there is the mention of possible future agreements in other areas and of cooperation with (and in) third countries. Paragraph IV (Cooperation Mechanisms) provides for a joint Italy-China Government Committee to monitor cooperation, while Paragraph V (Settlement of Differences) confirms the preference for solutions other than legal ones in case of interpretative disagreement, as it states that "the Parties will settle amicably differences in the interpretation of this Memorandum of Understanding through direct consultations." Doubts have been cast over the consistency between Paragraphs IV and V:

Paragraph V of the MoU (Settlement of Differences) reads indeed 'The Parties will settle amicably differences in the interpretation of this Memorandum of Understanding through direct consultations.' However, this is not true, because that claim is already is already neutralized at paragraphs IV and VI of the same MoU. Paragraph IV (Cooperation Mechanism) does in fact bind the parties to the 'full use of existing 
bilateral mechanisms', which, of course, are not included in the declaration of intents, however, were already established by previous bilateral agreements, ratified and implemented in the domestic law of both the Italian Republic and the People's Republic of China. $^{22}$

However, we think that a conforming interpretation is possible, although these provisions are undoubtedly ambiguous on purpose. Finally, Paragraph VI ("Applicable Law") confirms the soft law nature of this MoU and corresponds to similar clauses included in other Memoranda. Paragraph IV of this MoU reads:

This Memorandum of Understanding does not constitute an international agreement which may lead to rights and obligations under international law. No provision of this Memorandum is to be understood and performed as a legal or financial obligation or commitment of the Parties. This Memorandum of Understanding will be interpreted in accordance with the legislations of the Parties and as well as applicable international law and, as for the Italian Party, with the obligations arising from its membership of the European Union.

It is possible to find similar provisions in other Memoranda, for instance, in the one signed between China and the Philippines. ${ }^{23}$ What does it mean? Does this confine this kind of MoU to a mere propaganda dimension? And why do these Memoranda contain such ambiguous provisions? The BRI has indeed no treatybased institutional frame since it is "an initiative for which there are no publiclystated KPI, no overarching institutionalization, no formal membership protocols, no founding charters, and a timeline for development that is not measured in mere years, but decades. ${ }^{24}$ Not by coincidence, Wang defined the BRI as "a hub-andspoke network, with China as the hub," while the "spokes, therefore, are 'software' (mechanisms and agreements) and 'hardware' (e.g., devising economic corridors with BRI states) with different BRI states. ${ }^{25}$ Seen from this perspective, the BRI does not claim to overcome or replace existing international organisation but rather tries to interact with (and perhaps take advantage of) other institutionalised subjects by presenting itself as complementary. Against this background, soft law plays a twofold function:

First, from the perspective of international relations, it helps alleviate the concerns of the BRI countries, especially China's neighbours, that China will use the BRI to 'assert 
regional leadership in Asia' economically, diplomatically and militarily. Not requiring the parties to make hard commitments under binding legal obligations will reduce the fear of the BRI countries that, given the power asymmetry between them and China, as well as the uncertainty about China's intention and future, specific and binding commitments will make them vulnerable to Chinese dominance. ${ }^{26}$

This also confirms the instrumentality of law in the spirit characterising the BRI, although two international commercial courts have been set up to deal with possible disputes about the BRI. ${ }^{27}$ Here, the temporal factor matters. In this regard, the BRI - if carried out - will keep China and its partners busy for years; that is why institutional flexibility is an added value as priorities and agendas might change in light of the contingencies. In this sense, both normative and institutional flexibility might provide the BRI with adaptiveness and pragmatism, two key elements for such a big enterprise that is supposed to involve many public and private subjects. Concerns in terms of transparency and ambiguity remain, but these are connected with the BRI per se, rather than with the use of soft law.

Indeed, as we saw previously, soft law is above all a multi-function device: it refers to a universe of measures and acts which may have legal relevance depending on the context in which they are employed. In a strong integrated system like that of the EU-provided with direct effect and primacy and with strong common institutions-soft law has acquired an interesting role before the courts. ${ }^{28}$ In the Canadian case, especially with regard to the Social Union Framework Agreement (SUFA), soft law has been employed to galvanise political mediation and consensus, thereby avoiding the involvement of judges. For different reasons, this seems the desired goal in the design of the BRI. In the case of the BRI, however, there are additional motives for scepticism, in spite of the reassurances of the Supreme People's Court, according to which "the rule of law is an important safeguard for the BRI, in which the role of the judiciary is indispensable.",29

\section{Trade and Investment Disputes between CHINA AND THE EU}

BRI projects financed and carried out by Chinese companies continue to be based on flexible legal instruments that tend to avoid multilateral BRI treaties and 
institutions. ${ }^{30}$ China's BRI projects are often more based on informal, bilateral and state-centered practices than the US post-war leadership for the multilateral Bretton-Woods Agreements, GATT, the WTO and multilateral trade adjudication. China has been a party to the World Bank Agreement establishing the International Center for the Settlement of Investment Disputes (ICSID) for more than 25 years; it has also complied with the most adverse WTO dispute settlement rulings. ${ }^{31}$ These ICSID and WTO dispute settlement procedures are also available for the settlement of trade and investment disputes linked to BRI projects. Yet, China's BRI dispute settlement strategy has prioritized commercial arbitration in China's International Commercial Court (CICC) of the Supreme People's Court, ${ }^{32}$ or other Chinese arbitration institutions like the China International Economic and Trade Arbitration Commission (CIETAC) and its Silk Road Arbitration Center in Xi'an in cooperation with other arbitration centers in Asia (e.g. in Hong Kong and Singapore), Africa and Europe. The lack of a multilateral dispute settlement strategy distinguishes the BRI from the past US leadership for multilateral dispute settlement systems in GATT, ICSID, the WTO and regional free trade agreements (FTAs). Instead, China follows diverse, complementary dispute settlement methods and emphasizes the advantages of political dispute settlement methods over third party adjudication.

At least, the following seven kinds of BRI dispute settlement systems should be distinguished; their often "overlapping jurisdictions" may lead to "strategic forum shopping." 
Table 1: Seven BRI Dispute Settlement Systems

\begin{tabular}{|c|c|}
\hline Dispute & Operation \\
\hline Trade & $\begin{array}{l}\text { tend to be settled by China through multilateral WTO dispute settlement } \\
\text { procedures or through bilateral and regional negotiations. The } 2010 \\
\text { ASEAN-China FTA (as amended in 2018) provides for settlement of } \\
\text { disputes through consultations, mediation, conciliation or arbitration. }\end{array}$ \\
\hline Investment & $\begin{array}{l}\text { tend to be settled through bilateral negotiations in the context of China's } \\
\text { more than } 130 \text { bilateral investment treaties (BITs) rather than through } \\
\text { the very small number, so far, of ICSID or UNICITRAL arbitration } \\
\text { proceedings involving the PRC or companies from the PRC. }\end{array}$ \\
\hline Finance & $\begin{array}{l}\text { seem to be settled through bilateral negotiations, arbitration and other } \\
\text { jurisdictions in China rather than through multilateral treaty institutions } \\
\text { like the AIIB, which provides for settlement of disputes concerning loans } \\
\text { from this bank through UNCITRAL arbitration. }\end{array}$ \\
\hline $\begin{array}{l}\text { Intellectual } \\
\text { property }\end{array}$ & $\begin{array}{l}\text { may be settled through Chinese jurisdictions (like China's Patent office } \\
\text { and Chinese courts) or through WTO, WIPO and other multilateral } \\
\text { dispute settlement procedures. }\end{array}$ \\
\hline Commerce & $\begin{array}{l}\text { settled through Chinese courts and commercial arbitration procedures, } \\
\text { subject to various limitations of the legal admissibility of ad hoc arbitration } \\
\text { inside China (e.g. private ad hoc arbitration may be allowed inside China } \\
\text { only inside Free Trade Zones and certain arbitration centers). }\end{array}$ \\
\hline Maritime & $\begin{array}{l}\text { China refused participating in the UNCLOS dispute settlement procedures } \\
\text { initiated by the Philippines and rejected the } 2016 \text { arbitration award } \\
\text { concerning the South China Sea. }\end{array}$ \\
\hline $\begin{array}{l}\text { Energy trade } \\
\text { and investment }\end{array}$ & $\begin{array}{l}\text { China is not among the more than } 75 \text { members of the } 1998 \text { Energy } \\
\text { Charter Treaty, which provides for international state-state and investor- } \\
\text { state arbitration (ISA) of energy disputes and related investments. }\end{array}$ \\
\hline
\end{tabular}

Source: Compiled by the authors.

This potential diversity of BRI disputes seems to confirm that creating a single dispute settlement mechanism for settling all potential disputes along the BRI would be neither feasible nor desirable. Yet, the pragmatic "trial and error" approach of China vis-à-vis dispute settlement of BRI projects may be insufficient, for instance, regarding countries that are not WTO members, with which China has not concluded a BIT or an FTA, or whose domestic judicial systems for 
the settlement of economic disputes are not reliable. ${ }^{33}$ The diversity of dispute settlement fora for BRI related disputes invites "forum shopping," for instance, in case of disputes over intellectual property rights protected by the WIPO conventions, the WTO Agreement on trade-related intellectual property rights (TRIPS), and international investment law. So far, China seems to have hardly initiated any WTO disputes and investment arbitration disputes related to Silk Road projects. If host countries asked for adjustments to Silk Road Projects, political dispute settlements and contract re-negotiations were the preferred methods of agreed dispute settlement. Like China, many other Asian countries often prefer political rather than judicial dispute settlement methods (as illustrated by the rejection of ICSID by India, Thailand and Vietnam). The disregard for the WTO legal obligation (under Article IX:1 WTO Agreement) to appoint vacant WTO AB positions by majority votes, if necessary, illustrates that some WTO members may not be unhappy about the US initiative to destroy the WTO AB review system, which - since December 11, 2019 -has been no longer capable of accepting new appeals or completing all the 13 pending appellate review procedures. The draft Regional Comprehensive Economic Partnership (RCEP) Agreement between China and 14 other Asian countries, which is scheduled to be finalized in 2020, does not provide for a regional judicial and appellate review system that could compensate for a breakdown of the international rule of law at the worldwide level of the WTO governance.

The prioritization of bilaterally agreed, political dispute settlements has also become characteristic for the EU's external trade, investment and economic cooperation agreements. In the EU treaty practices, as disputes tend to be settled in bilateral treaty committees, treaty provisions for international arbitration have, so far, been rarely invoked by the EU (e.g. recently for the settlement of disputes over Korea's compliance with rules on worker rights in the EU-Korea FTA). This preference of both China and the EU for settling international financial and investment disputes politically stands in sharp contrast to the legalization and judicialization of trade, investment and financial disputes inside the EU. The Achmea judgment of the CJEU of March $2018^{34}$ on the inconsistency of BITs among the EU member states with the EU constitutional law and its judicial remedies entails that -according to the EU Commission-"all investor-State arbitration clauses in intra-EU BITs are inapplicable and that any arbitration 
tribunal established on the basis of such clauses lacks jurisdiction due to the absence of a valid arbitration agreement. ${ }^{35}$ In a Declaration of 15 January 2019 on the legal consequences of the Achmea judgment and on investment protection, 22 EU member states committed to terminate their-altogether more than 80 -intraEU BITs by December 2019, if possible. They will no longer interpret the Energy Charter Treaty as including ISA clauses applicable in relations among the EU member states. ${ }^{36}$ Some of the EU's constitutional guarantees of fundamental rights and economic freedoms also protect Chinese investors and workers inside the EU. For instance, according to Article 15.3 of the EU Charter of Fundamental Rights (the EUCFR), "[n]ationals of third countries who are authorized to work in the territories of the Member States are entitled to working conditions equivalent to those of citizens of the Union." Article 17.1 the EUCFR provides:

\begin{abstract}
Everyone has the right to own, use, dispose of and bequeath his or her lawfully acquired possessions. No one may be deprived of his or her possessions, except in the public interest and in the cases and under the conditions provided for by law, subject to fair compensation being paid in good time for their loss. The use of property may be regulated by law in so far as is necessary for the general interest.
\end{abstract}

Hence, the EU fundamental rights may be relied upon to ensure adequate protection of Chinese investors and of their workers carrying out Silk Road projects inside the EU member states. Past infringement actions by the EU Commission underscore its willingness to act on its own to protect foreign investors inside the EU member states from measures taken by their host states, rather than leave it only to those investors to seek judicial remedies. ${ }^{37}$ The jurisprudence of the CJEU continues clarifying investor protection under the EU law by member states' courts in the wake of the Achmea Judgment. This may also incentivize foreign investors, or their workers, to seek damages in host country's courts for failures to comply with investment protection obligations and fundamental rights under the EU law. In such disputes related to Silk Road investment projects inside the EU member states, national and the European courts will be legally bound to apply the European fundamental rights and constitutional law as parts of the applicable law. If the aim of concluding an EU-China BIT by the end of 2020 should be realized, ISA composed of professional judges will be also available for the settlement of the BRI-related investment disputes, with the applicable law essentially limited 
to the BIT provisions and applicable general international law. The advisory opinion by the CJEU of 30 April 2019 on the consistency with the EU law of the investment court system of the Comprehensive Economic and Trade Agreement (CETA) of the EU with Canada sets out clear constitutional limits for future ISA in a China-EU investment agreement. ${ }^{38}$ China neither participated in the arbitral proceeding under the UN Convention on the Law of the Sea (UNCLOS) initiated by the Philippines against China in 2013, nor recognized the arbitral award of 2016 rejecting China's claims to more than 80 percent of the South China Sea. In this respect, it remains doubtful whether China will support the EU proposals for a multilateral investment court.

As the demands of justice, and of legal and judicial justification, may differ according to the particular contexts, the principles of justice applicable to market and business transactions, labor contracts, "justice at the workplace," and "just compensation" for direct or indirect expropriation of property rights in the EUChina relations may differ from those developed by national and European courts for foreign investments by the EU citizens among the EU member states. Yet, human rights - as a type of fundamental rights focusing on respect for everyone's dignity and humanity - are recognized as "general principles of the Union's law",39 that protect Chinese workers and investors inside the EU no less than workers and investors with the EU passports. The EU human rights law, constitutional law and social legislation tend to limit "market failures" and "governance failures" much more strictly than in some authoritarian countries in Asia, which often protect much lower minimum standards of welfare and well-being. As Chinese SOEs may not yet fully respect civil, political, economic, social and cultural rights in a global standard and the ordo-liberal competition and social laws in social market economies, their implementation of Silk Road projects inside the EU member states may give rise to legal conflicts. An example is "justice at work" in the power relationships between Chinese employers and their employees inside the EU member states when liberal values like equal individual freedoms, privacy and co-determination of workers are disregarded. The settlement of such conflicts inside the EU may entail judicial dispute settlement procedures different from ISA, mediation and conciliation. It remains to be seen whether the ongoing negotiations on reforms of ICSID and UNCITRAL arbitration procedures, and the EU proposals for a multilateral investment court system, will strengthen the public law 
dimensions of investor-state disputes in ways that will also be accepted by China; and whether the jurisprudence of the CJEU and of the European Court of Human Rights (ECtHR) on protecting human rights as worker rights will strengthen the legal disciplines for foreign investors inside the $\mathrm{EU}$ and the protection of their workers, for instance, by limiting the terms of labor contracts through mandatory principles of constitutional law and human rights law aimed at guaranteeing "justice at work for all." ${ }^{40}$

\section{Conclusion: Multilevel Protection of Rule of Law in Silk Road Investment Projects?}

International trade, competition, investment, social and environmental laws need new rules in order to better take into account the risks of market failures and governance failures in relations between neo-liberal economies, state-capitalist economies, and ordo-liberal economies. The more globalization transforms national into transnational Public Goods (PGs) which no state can unilaterally protect without international law and cooperation, the more multilevel governance of transnational PGs requires multilevel protection of transnational rule of law. Also, the legitimacy of economic, financial and investment cooperation in the implementation of the BRI projects depends on rules-based legal frameworks, impartial dispute settlement procedures, predictability and compliance of governance with the "rule of law" as "a principle of governance in which all persons, institutions and entities, ... including the State itself, are accountable to laws that are publicly promulgated, equally enforced and independently adjudicated, and which are consistent with international human rights norms and standards" that have become part of universally recognized human rights principles. ${ }^{41}$

The current US-China trade wars were caused by (1) geopolitical rivalries and mercantilist zero-sum-conceptions of international trade advocated by the US Trump administration; (2) American neo-liberal interest-group politics resorting to illegal "trade remedies" and the US disruption of the WTO dispute settlement system; and (3) systemic conflicts between China's totalitarian state-capitalism and liberal interpretations of the WTO law. ${ }^{42}$ The "phase-one economic and trade agreement between China and the US," signed on January 15, 2020, reflects 
these systemic conflicts. While the Preamble acknowledges that it is "in the interest of both countries that trade grow," the agreement leaves - arguably WTOinconsistent, illegal - discriminatory US tariffs on imports from China worth up to USD 360bn in place; it includes discriminatory commitments of China to increase its purchases of the US goods and services up to a total amount of USD $200 \mathrm{bn}$ during 2020/2021, thereby strengthening China's state-capitalist quantitative trade management, while other agreed provisions (e.g. on 'forced' technology transfer, currency manipulation) aim at rules-based market-opening and at legal disciplines limiting market distortions in China, without mentioning discriminatory US restrictions on Chinese technology firms like Huawei. The bilateral dispute settlement procedure provides for the possibility of unilateral, discriminatory trade sanctions inconsistent with the WTO rules and the WTO dispute settlement procedures. The incoherent character of this partial "trade truce" is also illustrated by the absence of rules on many of the systemic US complaints of Chinese trade distortions (e.g. by industrial subsidies, SOEs, China's technology policies and cyber theft). The hegemonic, geopolitical rivalries underlying this "phase-one truce" suggest that the US trade war risks continuing indefinitely. Similarly, the agreement announced by the US, the EU and Japan in January 2020 on tougher subsidy disciplines aimed at Chinese SOEs remains unenforceable due to the simultaneous US disruption of the WTO legal and dispute settlement system. ${ }^{43}$ Continuing trade conflicts appear unavoidable not only between China's totalitarian state capitalism and the interest-group-driven, American neo-liberalism, where economic and environmental law-making are dominated by rent-seeking interest groups and by their financial support for congressmen and trade politicians. As illustrated by the US sanctions against Chinese technology companies, the US trade war against China and the increasing use by the US of trade sanctions as a foreign policy instrument also affect third countries and the future of the WTO.

Following the 2016 "Brexit referendum" and the US election of President Trump, the executive trade policies of both the British and US governments increasingly avoided multilateral legal disciplines, parliamentary and judicial control in relations with the European trading partners, as well. ${ }^{44}$ This increasing recourse to inter-governmentalism and power-related conflicts is likely to further undermine multilateral trade rules and adjudication. Other WTO member countries increasingly emulate the US tactics of preventing judicial clarifications of the 
WTO rules. For example, a draft WTO panel report of spring 2019 on China's complaint against the EU anti-dumping measures found that Section 15 of China's WTO Accession Protocol does not prevent other WTO members from applying non-discriminatory "distortion of competition principles" in their application of antidumping laws to imports from China. ${ }^{45}$ China's suspension of this WTO complaint after the interim review of the panel findings ushered in the non-publication and non-adoption of this panel report and of its important clarification of WTO legal disciplines. As China refused to accept the OECD principles on artificial intelligence, and its "Made in China 2025" program aims at import substitution and technological independence, the EU countries have introduced stricter surveillance of foreign direct investments from China. Many WTO members continue to criticize China for not adequately meeting its transparency requirements under the WTO law. The more the US assault on the WTO legal and dispute settlement system limits political and judicial clarifications of the often contested meaning of WTO rights and obligations, the more China may find it preferable to prioritize its bilateral BRI and RCEP projects for constructing a China-centered "Eurasian trading system." It could replace the US as China's main export market and enable statecapitalist economies to become "rule-makers" defending their authoritarian control of economies and polities also in transnational cooperation.

Since China's first BIT concluded in 1982, China has accepted full ICSID jurisdiction since 1998 and pre-establishment national treatment commitments since 2013 (subject to exceptions). China concluded more than 50 BITs with BRI partner countries; the number of FTAs concluded by China remains, however, much smaller. ${ }^{46}$ China's new foreign investment legislation approved in 2019 reflects the changing investment policies. It has been criticized as "a missed opportunity" to stop the downward trend of foreign direct investment in China. ${ }^{47}$ The number of ICSID arbitration procedures for settling disputes involving China as a respondent (three cases only by July 2017), or introduced by Chinese investors abroad as complainants (five ISAs by July 2017), remains exceptionally low. ${ }^{48}$ China has played a leading role in the adoption of the 2017 "Guiding Principles for Global Investment Policymaking" by the G20. Yet, the EU officials criticize China for the "snail pace progress" in the many years of negotiations on a China-EU investment agreement and for making access of the European companies to the Chinese market often conditional on joint ventures and technology transfers. The recent 
EU proposal for a Regulation reviewing FDI by Chinese companies reflects the EU's cautious attitude vis-à-vis Chinese SOEs and Chinese geopolitical influence. It remains to be seen how China-in case the US assault on the WTO dispute settlement system should adversely affect other WTO governance functions will respond to the dismantling of the WTO provisions for horizontal and vertical separation of legislative, administrative and judicial WTO governance powers and mutual "checks and balances." The US trade war against China risks undermining the important role which international law has so far played in furthering economic and legal reforms inside China.

The systemic conflicts between Chinese state-capitalism, Anglo-Saxon neoliberalism and the European ordo-liberal, multilevel constitutionalism suggest increasing bilateral and regional challenges to the WTO legal and dispute settlement system, for instance, in the implementation of the EU's "New Green Deal" for climate change mitigation through carbon taxes and border carbon adjustments. The BRI projects are driven by Chinese economic, political and legal interests including China's preference for maintaining legal flexibility, Chinese top-down governance and China's self-interest in becoming a "rule-maker" in new policy fields like the cyberspace and patent registration. The EU is currently designing a multilateral counter-strategy, insisting on China's compliance with the EU law in carrying out BRI projects inside the EU. From an EU perspective, BRI related trade and investment disputes may be better settled through the WTO and investment arbitration than through Chinese court and arbitration proceedings applying Chinese law, whose consistency with the EU constitutional law guarantees ${ }^{49}$ appears doubtful. Currently, $17 \mathrm{EU}$ member states have joined the China-led AIIB, and 11 participate in BRI projects, which are discussed in a 17+1 institutional framework. Agreement on common EU positions on China's BRI initiative would be facilitated by conclusion of the proposed EU-China investment agreement and by China's accession to the WTO Government Procurement Agreement so as to protect reciprocal market access rights, investor rights and other fundamental rights and judicial remedies. The breakdown of the WTO dispute settlement system risks adversely affecting the impact of the WTO law on China's continuing "rule by law construction." The constitutional requirement of the EU under Article 3 of its Lisbon Treaty to contribute to "the sustainable development of the Earth," "free and fair trade," "the protection of human rights" and "to the strict observance 
... of international law" will be closely watched by European civil societies and democratic institutions in future the EU cooperation with China.

Notably in the implementation of the EU's "New Green Deal" for climate change mitigation through reducing greenhouse gas emission, the EU's introduction of taxes on carbon-emissions and related border carbon adjustments are likely to give rise to increasing conflicts with other large carbon emitters like China, India and the US. China's use of the WTO law for promoting "rule by law" in China's multilevel governance of transnational trade reflects a 'thin,' formal conception of rule of law that does not meet all the formal criteria (like publicity, prospective application, generality, clarity, consistency, performability, stability over time, congruity between the positively enacted and actually practiced law) and institutional criteria (like an independent judicial system) of what Fuller called the "internal morality of law." China's legal system and "rule by law" are even less consistent with substantive conceptions of rule of law, notably with the human and constitutional rights protected by the EU law, by UN human rights and labor rights conventions, or by the definition of "rule of law" in UN reports. This systemic rivalry between China's totalitarian state-capitalism (e.g. using extremely low labor costs and state subsidies for its export-led growth model) and Europe's rights-based "social market economy" (based on multilevel human rights and democratic constitutionalism) is likely to remain a source for regular conflicts in the cooperation among China and Europe, which would be resolved best through multilateral, rules-based legal and dispute settlement systems. It remains paradoxical that - even though the WTO remains the only worldwide organization capable of negotiating multilateral competition and legal disciplines for SOEs, state subsidies and other market distortions - the Trump administration has given up Western leadership for using the WTO law and dispute settlement procedures as constraints on systemic, competitive distortions and abuses of power inside China. 


\section{REFERENCES}

1. For details, see National Development and Reform Commission (Ministry of Foreign Affairs and Ministry of Commerce of the People's Republic of China), Vision and Actions on Jointly Building Silk Road Economic Belt and 21st-Century Maritime Silk Road (Mar. 2015), available at https://www.fmprc.gov.cn/mfa_eng/zxxx_662805/t1249618.shtml.

2. See generally L. Xing, Mapping China's 'One Belt One Road’ Initiative (2019); Y. Cheng et al., The Belt \& Road Initiative in the Global Arena: Chinese and European Perspectives (2018); M. Mayer, Rethinking the Silk Road China’s Belt and Road Initiative And Emerging Eurasian Relations (2018).

3. See generally Yun Zhao, International Governance and the Rule of Law in China under the Belt and Road Initiative (2018); J. Chaisse \& J. Górski, The Belt and Road Initiative Law, Economics, and Politics (2018); W. Shan et al., Normative Readings of the Belt and Road Initiative. Road to New Paradigms (2018).

4. H. Wang, China's Approach to the Belt and Road Initiative: Scope, Character and Sustainability, 22 J. InT'L ECon. L. 29 (2019).

5. Case C-399/11, Stefano Melloni v Ministerio Fiscal, 2013 ECLI:EU:C:2013:107.

6. J. Chaisse \& J. Kirkwood, Chinese Puzzle: Anatomy of the (Invisible) Belt and Road Investment Treaty, 23 J. INT'L Econ. L. 245 (2020).

7. "To sum up, soft law is preferred to treaties in China's BRI approach. Although existing treaties remain relevant, the BRI does not have many formal international law instruments. There is no BRI-wide treaty or similar international law instrument establishing the BRI. The BRI neither has a constituting treaty with all BRI states (a BRI-wide treaty) nor formal membership protocols. China, as such, does not appear to have a strong intention to bring in BRI-wide hard law obligations at this stage..." Wang, supra note 4, at 43.

8. Wang, supra note 4 , at 31.

9. J. Wang, China's Governance Approach to the Belt and Road Initiative (BRI): Partnership, Relations, and Law (National University of Singapore Faculty of Law Legal Studies Working Paper Series No. 2019/005), available at https://papers.ssrn.com/sol3/ papers.cfm?abstract_id=3346427\#.

10. Id.

11. "We immediately recognize that the question is not necessarily one of hard versus soft law: there is also the issue of the possible interaction between these two approaches to governance and thus of "hybrid" constellations in which both hard and soft processes operate in the same domain and affect the same actors." See D. Trubek et al., 'Soft law', 'Hard law', and European integration: toward a theory of hybridity 2 (Jean Monnet Working Papers, 2005), available at https://ideas.repec.org/p/erp/jeanmo/p0242.html.

12. Wang, supra note 4, at 32. 
13. Id. at 42 .

14. F. Snyder, Soft Law and Governance: Aspects of the European Union Experience, in THE Challenge of Soft Law (Luo Haocai ed., 2009), available at https://papers.ssrn.com/ sol3/papers.cfm?abstract_id $=3101617$.

15. C. Chinkin, Normative development in the international legal system, in COMMITMENT AND Compliance: the Role of Non-Binding Norms in the International Legal System 28 (D. Shelton ed., 2003).

16. O. Stefan, Soft Law in Court: Competition Law, State Aid and the Court of Justice of THE EUROPEAN UNION 9 (2012).

17. "Reflecting Chinese culture, China takes a flexible 'middle-of-the-road' strategy in respect of the BRI, avoiding extremes or 'radical' development." See Wang, supra note 4 , at 53.

18. L. Di Matteo, 'Rule of Law' in China: The Confrontation of Formal Law with Cultural Norms, 51 CoRnell InT'L L. J. 440-1 (2018).

19. E. Clark, China's 'soft law' a major factor for success in future, CHINA.ORG.CN (Oct. 17, 2013), available at http://www.china.org.cn/opinion/2013-10/17/content_30321578.htm.

20. See What is the China-Italy MoU?, OBOReurope, Mar. 24, 2019, available at https:// www.oboreurope.com/en/what-is-the-china-italy-mou.

21. Supra note 1.

22. See The trap of the Italian-Chinese Memorandum of Understanding, LA Voce Di TRIESTE, May 18, 2019), available at https://www.lavoceditrieste.net/2019/05/18/the-trap-of-theitalian-chinese-memorandum-of-understanding.

23. "This Memorandum of Understanding does not create legally binding obligations for the Participants. It is an expression of their common aspiration to cooperate on the Belt and Road Initiative for the mutual benefits." See Memorandum of Understanding between the Government of the Republic of the Philippines and the Government of the People's Republic of China on Cooperation on the Belt and Road Initiative (Nov. 20, 2018), available at https://rappler.com/nation/document-philippines-china-deal-belt-road-initiative.

24. W. Shepard, Why the Ambiguity of China's Belt and Road Initiative Is Perhaps its Biggest Strength, ForBes, Oct. 19, 2017, available at https://www.forbes.com/sites/ wadeshepard/2017/10/19/what-chinas-belt-and-road-initiative-is-really-all-about/\#1f9e89 ede4de.

25. Wang, supra note 4 , at 35.

26. Wang, supra note 9.

27. Wang, supra note 9. See also Singapore International Mediation Centre, Two for the Road: China's International Commercial Courts (Aug. 17, 2018), available at http://simc. com.sg/blog/2018/08/17/two-road-chinas-international-commercial-courts.

28. Stefan, supra note 16.

29. Several Opinions of the Supreme People's Court on the Judiciary's Provision of Judicial 
Services and Safeguard for the Belt and Road [最高人民法院关于人民法院为 “一带一路” 建设提供司法服务和保障的若干意见], recited from Wang, supra note 9.

30. The 2015 Agreement establishing the Asian Infrastructure and Investment Bank (AIIB) and the 2001 Shanghai Cooperation Organization - even though initiated by China and having their headquarters at Beijing - have mandates far beyond BRI cooperation.

31. See generally W. Zhou, China's Implementation of the Rulings of the World Trade Organization (2019).

32. H. Jiang, Demystifying China's International Commercial Court Regime: International or Intra-National?, 36 Chinese (TAIwAN) Y.B. InT'L L. \& AfF. 171 (2018).

33. On the risks of non-enforcement of arbitral awards in Asian BRI countries (e.g. due to invocation of the "public policy exception" in Article V:2(b) of the New York Convention on the Recognition and Enforcement of Foreign Arbitral Awards), and on the advantages of harmonizing the "public policy concept" in the cross-border enforcement of arbitral awards among Asian countries, see W. Gu, Belt and Road Dispute Resolution: New Development Trends, 36 Chinese (Taiwan) Y.B. Int'L L. \& Aff. 151 (2018).

34. Case C-284/16, The Slovak Republic v. Achmea BV, ECLI:EU:C:2018:158.

35. See Communication from the Commission to the European Parliament and the Council, Protection of intra-EU investment, COM (2018) 547 final (July 19, 2018), at 26, available at https://eur-lex.europa.eu/legal-content/EN/TXT/PDF/?uri=CELEX:52018D C0547\&rid $=8$.

36. European Commission, Declaration of the Member States of 15 January 2019 on the legal consequences of the Achmea judgment and on investment protection (Jan. 17, 2019), available at https://ec.europa.eu/info/publications/190117-bilateral-investment-treaties en.

37. Commission v Hungary, Case C-235/17, (May 21, 2019) ECLI:EU:C:2019:432. See also, supra note 35 (providing "guidance to help the EU investors to invoke their rights before national administrations and courts and to help Member States to protect the public interest in compliance with the EU law.").

38. In Opinion 1/2017, the ISA procedures in the CETA were found to be consistent with the EU law in view of the legal limitations of the potential reach of ISA by CETA guarantees of, inter alia, the legal autonomy of the EU law, the EU judicial system, the democratic "regulatory freedom" to protect non-economic PGs, and of fundamental rights (e.g. of access to judicial remedies, equal treatment) as protected in the EUCFR. See Opinions of the Court concerning the case of Accord ECG UE-Canada, Opinion 1/2017 (Apr. 30, 2019) ECLI:EU:C:2019:341.

39. Treaty of Lisbon art. 6.

40. See generally H. Collins, Justice at Work (LSE Legal Studies Working Paper No. 18/2019), available at https://ssrn.com/abstract=3486179.

41. UN. Doc. G.A. Res. 67/97 (Jan. 14, 2013). 
42. E.-U. Petersmann, Economic Disintegration? Political, Economic and Legal Drivers and the Need for 'Greening Embedded Liberalism', 23 J. InT'L Econ. L. (2020), available at https://doi.org/10.1093/jiel/jgaa005.

43. Due to the illegal "blockage" by the US of the appointment of AB members since 2017, there was only one single AB member left as of 11 December 2019. This rendered the $\mathrm{AB}$ uncapable of admitting new appeals. The EU-Initiative for a "Multi-Party Interim Appeal Arbitration (MPIA) Arrangement" under Article 25 of DSU, which is in effect as of 30 April 2020 for appellate review among 22 WTO members (including also China) until the WTO AB can resume its lawful functions, was notified to the WTO in the WTO document JOB/DSB/1/Add.12 of 30 April 2020. It was subsequently accepted by other WTO members, too, and has already been applied in several WTO disputes.

44. Petersmann, supra note 42.

45. See Lapse of Authority for the Establishment of the Panel, European Union-Measures Related to Price Comparison Methodologies, WTO Doc. WT/DS516/14 (June 15, 2020). After the panel issued its confidential interim panel report, China requested the panel to suspend its activities pursuant to Article 12.12 of DSU. As China did not request a resumption of the panel proceeding, the panel's jurisdiction lapsed on June 15, 2020 without publication of the panel report.

46. S. Jingxia, The Belt and Road Initiative and International Law: An International Public Goods Perspective, in International Governance and the Rule of Law in China under the Belt and Road Initiative 9 (Y. Zhao ed., 2018).

47. H. Broadman, China's new foreign investment law is a missed opportunity, Fin. Times, Dec. 24, 2019, available at https:/www.ft.com/content/2fb69129-2938-4ca0-a523$426 \mathrm{c} 8 \mathrm{bc} 259 \mathrm{ad}$.

48. Dae Un Hong \& Ju Yoen Lee, Why Are There So Few Investor-State Arbitrations in China?: A Comparison with Other East Asian Economies 4:1 China \& WTO Rev. 35 (2018).

49. E.g., individual rights to effective remedies and to a fair trial. $C f$. EUCFR art. 47.

50. L. Fuller, The Morality of Law 46 (1977).

51. UN Secretary-General, The rule of law and transitional justice in conflict and post-conflict societies, U.N. Doc. S/2004/616 (Aug. 23, 2004). This report defines the "rule of law" as a "principle of governance in which all persons, institutions and entities, public and private, including the State itself, are accountable to laws that are publicly promulgated, equally enforced and independently adjudicated, and which are consistent with international human rights norms and standards. It requires as well measures to ensure adherence to the principles of supremacy of law, equality before law, accountability to the law, fairness in the application of the law, separation of powers, participation in decision-making, legal certainty, avoidance of arbitrariness and procedural and legal transparency." 